\title{
The top 100 most cited articles on bronchoscopy: a bibliometric analysis
}

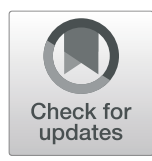

\author{
Boxue He ${ }^{1,2 \dagger}$, Pengfei Zhang ${ }^{1,2 \dagger}$, Qidong Cai ${ }^{1,2}$, Shuai Shi ${ }^{1,2}$, Hui Xie ${ }^{1,2}$, Yuqian Zhang ${ }^{1,2}$, Xiong Peng ${ }^{1,2}$, \\ Zhenyu Zhao ${ }^{1,2}$, Wei Yin ${ }^{1,2}$ and Xiang Wang ${ }^{1,2^{*}}$ (D)
}

\begin{abstract}
Background: Bronchoscopy is applied broadly in the diagnosis and treatment of pulmonary diseases. Over the past few decades, an increasing number of studies about bronchoscopy have been published. However, little is known about their qualities and characteristics.

Methods: All of the databases in Web of Science (including the Web of Science Core Collection, BIOSIS Citation Index, KCl-Korean Journal Database, MEDLINE, Russian Science Citation Index, and SciELO Citation Index) were utilized to identify articles published from 1990 to 2020. The top 100 most cited articles about bronchoscopy were selected for degree centrality analysis and analyses regarding publication time, total citation number, the citation density, time-related flux, first author, published journal, geographic origin, and research theme.

Results: The selected articles were published mainly in the 2000s and 1990s. Citations per article ranged from 731 to 196. The leading country was the USA, followed by the United Kingdom. The most frequently studied themes were bronchoalveolar lavage (BAL) fluid and biopsy. The degree centrality analysis connoted that "BAL, inflammation, diagnosis" had a high degree of centrality in the 1990s, while "diagnosis, BAL, biopsy, prospective" took centre stage in the 2000s.

Conclusions: The time, area, and theme distribution of the 100 most cited articles on bronchoscopy have been thoroughly analyzed. It is noticeable that researches based on BAL and endobronchial or transbronchial biopsies currently plays a major role.
\end{abstract}

Keywords: Citations, Most-cited papers, Bronchoscopy

\section{Introduction}

German laryngologist Gustav Killian performed the first bronchoscopy by using rigid bronchoscopy to remove a pork bone from a patient's airway in 1897 [1]. The procedure was performed while the patient was awake and cocaine was utilized as a local anesthetic. Nowadays, endoscopy techniques have developed into an approach

\footnotetext{
* Correspondence: wangxiang@csu.edu.cn

${ }^{\dagger}$ Boxue He and Pengfei Zhang contributed equally to this work.

'Department of Thoracic Surgery, The Second Xiangya Hospital, Central South University, Changsha 410011, Hunan, China

${ }^{2}$ Hunan Key Laboratory of Early Diagnosis and Precision Therapy, Department of Thoracic Surgery, The Second Xiangya Hospital, Central South University, Changsha 410011, Hunan, China
}

which can effectively detect and localize critical early pathological changes occurring in the bronchial epithelium and subepithelial regions of human bodies [2]. Bronchoscopies including autofluorescence bronchoscopy, optical fluorescence and reflectance spectroscopy, high-magnification bronchoscopy, high-frequency endobronchial ultrasound, optical coherence tomography, etc. remain a cornerstone in helping identify the etiology of radiographic abnormalities in human bronchial and lung [3]. Under the assistance of bronchoscopies, diseases which can be diagnosed cover chronic lung diseases such as asthma, chronic obstructive pulmonary disease, interstitial lung disease, some lung cancer, and even

C The Author(s). 2020 Open Access This article is licensed under a Creative Commons Attribution 4.0 International License, which permits use, sharing, adaptation, distribution and reproduction in any medium or format, as long as you give appropriate credit to the original author(s) and the source, provide a link to the Creative Commons licence, and indicate if changes were made. The images or other third party material in this article are included in the article's Creative Commons licence, unless indicated otherwise in a credit line to the material. If material is not included in the article's Creative Commons licence and your intended use is not permitted by statutory regulation or exceeds the permitted use, you will need to obtain permission directly from the copyright holder. To view a copy of this licence, visit http://creativecommons.org/licenses/by/4.0/ The Creative Commons Public Domain Dedication waiver (http://creativecommons.org/publicdomain/zero/1.0/) applies to the data made available in this article, unless otherwise stated in a credit line to the data. 
pulmonary infectious diseases [4-6]. It has aroused our interest that what are the common laws of the complex literature surrounding bronchoscopy these years, and how will it guide future research. Therefore, we hope to carry out a literature-based analysis of bronchoscopy.

There is a unique tool called bibliometrics for analyzing the quality and characteristics of published articles. It was first published in JAMA in 1987 and has been widely used in various fields to assess the importance of published articles or research trends [7]. Through a literature search, we found that there were quite a few highly cited literature (citation time $>150$ ) on bronchoscopy or utilizing bronchoscopy as the main research method, but no literature on bibliometrics analysis yet. The purpose of this study was to investigate the 100 most cited publications in the field of bronchoscopy, to highlight knowledge milestones in the field, and to analyze the quality and characteristics of the most cited original papers of the past 30 years. We also look forward to finding out the most promising research direction about bronchoscopy.

\section{Methods}

\section{Search strategy and criteria}

Web of Science (Thomson Reuters, New York, USA) allows access to more than 12,000 peer-reviewed journals published since 1945, along with their collected citation data [8]. On February 10, 2020, we searched online via all of the databases in Web of Science (including the Web of Science Core Collection, BIOSIS Citation Index, KCI-Korean Journal Database, MEDLINE, Russian Science Citation Index, and SciELO Citation Index). To enhance the sensitivity, two independent researchers used the same search terms ("bronchoscopy" OR "bronchoscopies" OR "bronchoscopic") with the determined period of 1990 to 2020 and without any language restrictions to search simultaneously. A total of 35,637 results were gathered, and after filtering by Literature type as "articles" and/or "clinical trial", 29,030 pieces of literature was listed. Thus, only typical original articles were included, and literature such as reviews, meta-analyses, and guidelines was excluded.

To reduce the number of articles that need to be screened and improve the gold content of selected documents, we then exported articles that have been cited at least 150 times to EndNote. These 423 articles included were all reviewed by two independent researchers based on the title and the abstract of each. Articles which met the following criteria were included to our study group: (1) The article mainly focuses on bronchoscopy (including rigid bronchoscopy, fiber bronchoscopy, fluorescent bronchoscopy, and so on) with the topic of technical improvement or evaluation; (2) The article compares the advantages or disadvantages of bronchoscopy and other examination or sampling methods; (3) The article mentions bronchial thermoplasty, bronchial valve surgery or other bronchoscope-based operation to solve clinical problems; (4) The article is mainly based on bronchoalveolar lavage (BAL) fluid or bronchoscopy biopsies to get samples for later research. The disagreement between the two researchers was discussed in sequence to reach an agreement. Finally, there remained 185 articles for the following research. These articles were ranked by the number of citations and the top 100 articles were included in this analysis (Fig. 1).

\section{Extraction}

All articles were reviewed by two independent experienced investigators. The following information was listed for all articles: the journal name, year of publication, article age (2020 minus the year of publication), first author, geographic origin, total citation number, the citation density (total citation number/article age), and research theme (introduced later).

\section{Statistical analysis}

The distribution of individual variables for normality was tested using the Shapiro-Wilk test and the KolmogorovSmirnov test. Normally distributed data were presented as mean \pm standard deviation. A comparison between means was performed using a one-way analysis of variance (ANOVA). Time-dependent trends were tested by the Mann-Kendall trend test. Correlation between variables was performed by the Spearman rank test. $P<0.05$ was considered to be statistically significant. The analysis was performed using IBM SPSS Statistics, Version 24.0. The Ucinet for windows, version 6.212 was used for the degree of centrality analysis. At last, we used the same search strategy to search 1000 most cited articles in the core data set of Web of Science, and then used HistCite Pro 2.1 software to re-analyze and compare with the formermentioned 100 articles.

\section{Results}

We gathered the 100 most cited articles on bronchoscopy (Table 1, Additional file 1). The number of citations ranged from 731 to 196 , and a majority of articles presented in the 2000s (50\%) and 1990s (42\%), while articles published in 2010s only accounted for 8\% (Fig. 2). The year with the highest number of articles was 2006 $(n=9)$, followed by $2007(n=8), 1995(n=7)$, and 1997 $(n=7)$. The mean number of citations was 290 overall, 293 in the 1990s, 276 in the 2000s, and 368 in the 2010s. The mean number of citation density was 17.5 overall, 12.0 in the $1990 \mathrm{~s}, 18.0$ in the 2000s, and 42.2 in the 2010s. The Mann-Kendall trend test showed an increasing trend between the top-cited articles' citation density and their published time $(P<0.0001)$ (Fig. 3). The Spearman rank showed a positive correlation between year of 


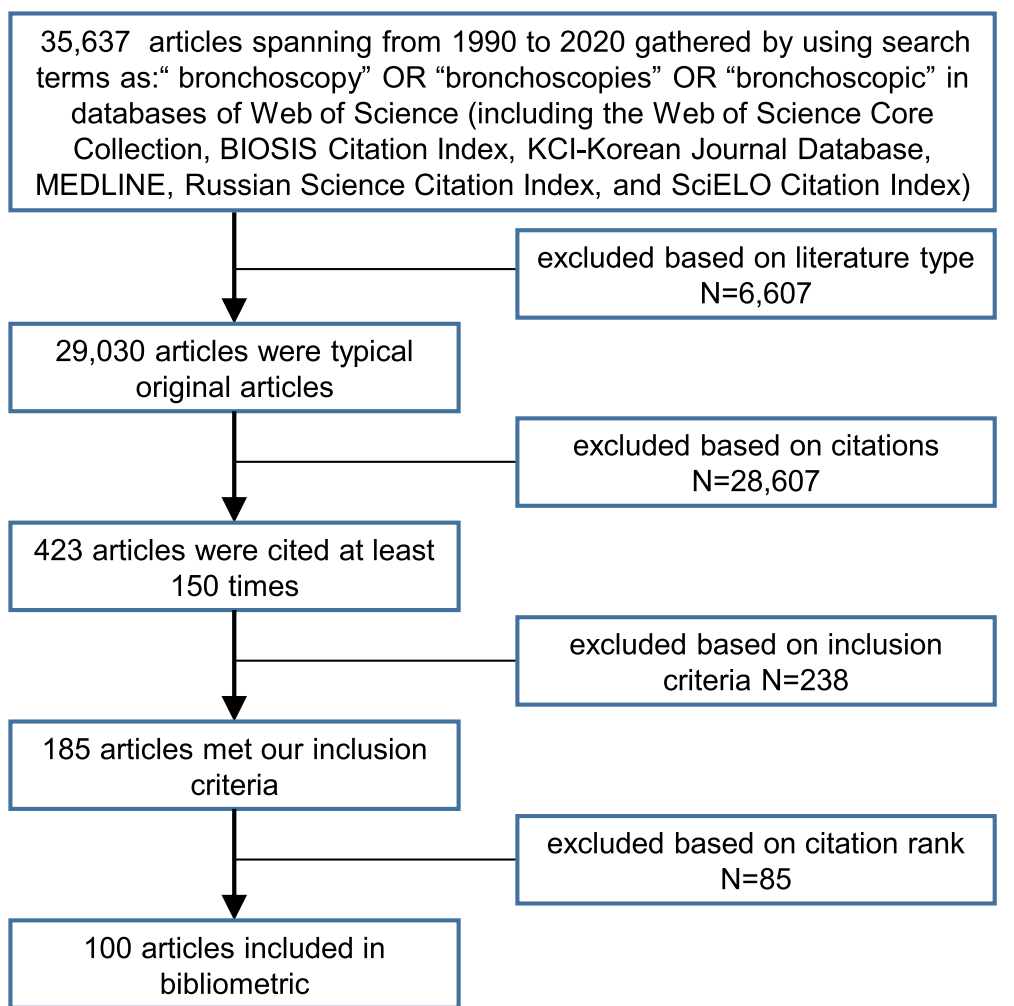

Fig. 1 Flowchart illustrating the article allocation process

publication and citation density $(r=0.764, P<0.01)$. Both the Shapiro-Wilk test and the KolmogorovSmirnov test indicated an abnormal distribution in total citation number as well as the citation density.

All of the articles were distributed in 16 countries, led by the USA $(n=35)$, followed by the United Kingdom $(n=14)$, France $(n=10)$, and so on. The distribution was illustrated on the world map (Fig. 4). The map showed that two regions, North America and Western Europe, kept most of the articles. Besides, Japan had 6 articles, Australia had 4, Argentina and Israel both had 2, while Korea had 1.

These articles were published in 25 kinds of journals. Thirty-nine articles were published in American journal of respiratory and critical care medicine, followed by Chest $(n=20)$, The American review of respiratory disease $(n=$ 5), Thorax $(n=5)$, New England Journal of Medicine ( $n=$ 4), Annals of Internal Medicine $(n=3)$, Pediatric Pulmo$n \operatorname{logy}(n=3)$, and other three journals $(n=2)$ (Table 2).

The first authors with the most occurrences and their basic research institutions were listed in Table 3. Yasufuku K, from Japan, had acted as the first authorship in four articles out of our list, in which two written in Chiba University, one in Department Hospital de Sabadell, and one in University of Toronto. The total citations of his four selected articles were 1484 .

We collected the research institutions of first authors in these top-cited articles. Eight institutions had 3 articles included, and they were Hospital Bichat, University of Barcelona, Royal Brompton Hospital, University of London, University of Southampton, Mayo Clinic, National Jewish Medical and Research Center, and University of California at San Francisco. Besides, 10 research institutions were involved by two articles listed, and 56 institutions with one article, respectively (Supplementary Table 1 ).

We divided these top 100 most cited articles into eight categories based on the main content. In particular, some articles cover two or three types of topics at the same time, and we also recorded them repeatedly. Three professional researchers discussed each article and reached consensus. List these theme categories in descending order according to the number of relevant literature as: BAL fluid $(n=50)$, bronchoscopy and biopsy $(n=29)$, comparison of different examinations $(n=19)$, evaluation of new technologies $(n=$ $12)$, bronchial thermoplasty $(n=4)$, new technique of bronchoscopy $(n=4)$, bronchoscope-based operation $(n=3)$, and bronchoscopy assisted valve implantation $(n=2)$ (Fig. 5). One-way ANOVA showed no significant difference between citations and these themes $(P=0.486)$ (Fig. 6).

These article's keywords and subject terms were checked one by one by two researchers, and then degree centrality analysis has been done in two periods of article published time: in the 1990s (42 articles) and the 2000s (50 articles). The result indicated that "BAL, inflammation, diagnosis, biopsy" had a high degree of 
Table 1 List of the 100 top-cited articles on bronchoscopy

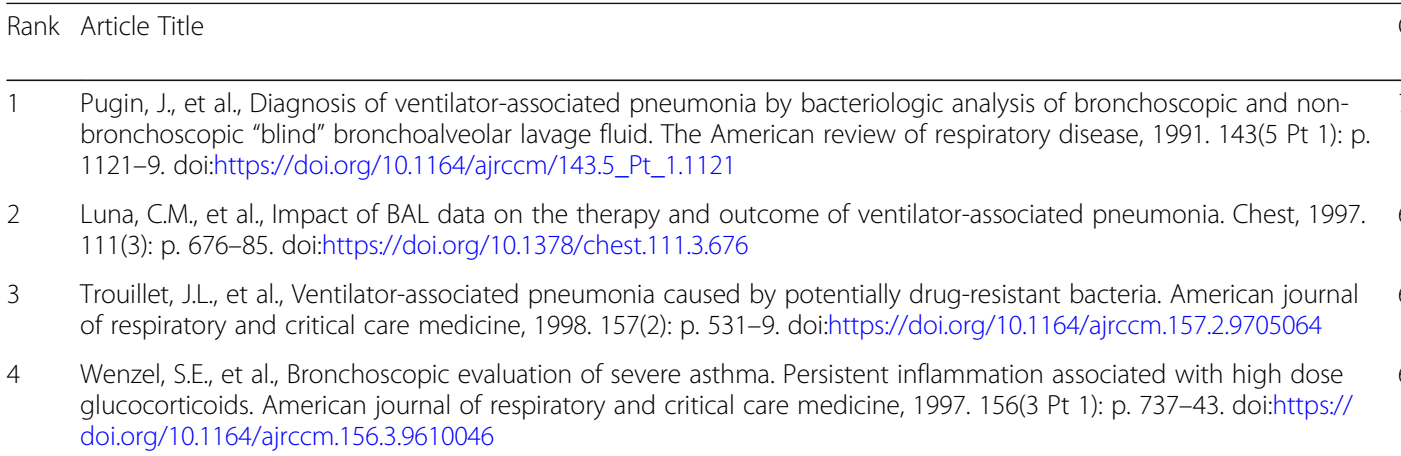

5 Fagon, J.Y., et al., Invasive and noninvasive strategies for management of suspected ventilator-associated pneumonia 530 - A randomized trial. Annals of Internal Medicine, 2000. 132(8): p. 621 - +. doi:https://doi.org/10.7326/0003-4819-1328-200,004,180-00004

6 Yasufuku, K., et al., Real-time endobronchial ultrasound-guided transbronchial needle aspiration of mediastinal and hilar lymph nodes. Chest, 2004. 126(1): p. 122-128. doi:https://doi.org/10.1378/chest.126.1.122

7 Sciurba, F.C., et al., A Randomized Study of Endobronchial Valves for Advanced Emphysema. New England Journal of Medicine, 2010. 363(13): p. 1233-1244. doi:https://doi.org/10.1056/NEJMoa0900928

8 Charlson, E.S., et al., Topographical Continuity of Bacterial Populations in the Healthy Human Respiratory Tract. American Journal of Respiratory and Critical Care Medicine, 2011. 184(8): p. 957-963. doi:https://doi.org/10.1164/ rccm.201104-06550C

9 Erb-Downward, J.R., et al., Analysis of the Lung Microbiome in the "Healthy" Smoker and in COPD. Plos One, 2011. 6(2). doi:https://doi.org/10.1371/journal.pone.0016384

10 Lam, S., et al., Localization of bronchial intraepithelial neoplastic lesions by fluorescence bronchoscopy. Chest, 1998. 113(3): p. 696-702. doi:https://doi.org/10.1378/chest.113.3.696

11 Howarth, P.H., et al., Tumour necrosis factor (TNF alpha) as a novel therapeutic target in symptomatic corticosteroid dependent asthma. Thorax, 2005. 60(12): p. 1012-1018. doi:https://doi.org/10.1136/thx.2005.045260

12 Kraft, M., et al., Alveolar tissue inflammation in asthma. American journal of respiratory and critical care medicine, 1996. 154(5): p. 1505-10. doi:https://doi.org/10.1164/ajrccm.154.5.8912772

13 Castro, M., et al., Effectiveness and Safety of Bronchial Thermoplasty in the Treatment of Severe Asthma A Multicenter, Randomized, Double-Blind, Sham-Controlled Clinical Trial. American Journal of Respiratory and Critical Care Medicine, 2010. 181(2): p. 116-124. doi:https://doi.org/10.1164/rccm.200903-03540C

14 Spira, A., et al., Effects of cigarette smoke on the human airway epithelial cell transcriptome. Proceedings of the National Academy of Sciences of the United States of America, 2004. 101(27): p. 10143-10,148. doi:https://doi.org/ 10.1073/pnas.0401422101

15 Saetta, M., et al., Airway eosinophilia in chronic bronchitis during exacerbations. American journal of respiratory and critical care medicine, 1994. 150(6 Pt 1): p. 1646-52. doi:https://doi.org/10.1164/ajrccm.150.6.7952628

16 Cox, G., et al., Asthma control during the year after bronchial thermoplasty. New England Journal of Medicine, 2007. 383 356(13): p. 1327-1337. doi:https://doi.org/10.1056/NEJMoa064707

17 Phillips, M., et al., Detection of lung cancer with volatile markers in the breath. Chest, 2003. 123(6): p. 2115-2123. doi:https://doi.org/10.1378/chest.123.6.2115

18 Spira, A., et al., Airway epithelial gene expression in the diagnostic evaluation of smokers with suspect lung cancer. Nature Medicine, 2007. 13(3): p. 361-366. doi:https://doi.org/10.1038/nm1556

19 Rello, J., et al., The value of routine microbial investigation in ventilator-associated pneumonia. American journal of respiratory and critical care medicine, 1997. 156(1): p. 196-200. doi:https://doi.org/10.1164/ajrccm.156.1.9607030

20 Yasufuku, K., et al., Comparison of endobronchial ultrasound, positron emission tomography, and CT for lymph node staging of lung cancer. Chest, 2006. 130(3): p. 710-718. doi:https://doi.org/10.1378/chest.130.3.710

21 Luna, C.M., et al., Resolution of ventilator-associated pneumonia: Prospective evaluation of the clinical pulmonary in- 351 fection score as an early clinical predictor of outcome. Critical Care Medicine, 2003. 31(3): p. 676-682. doi:https://doi. org/10.1097/01.ccm.0000055380.86458.1e

22 Yasufuku, K., et al., Endobronchial ultrasound guided transbronchial needle aspiration for staging of lung cancer. Lung Cancer, 2005. 50(3): p. 347-354. doi:https://doi.org/10.1016/j.lungcan.2005.07.013

23 Grainge, C.L., et al., Effect of Bronchoconstriction on Airway Remodeling in Asthma. New England Journal of Medicine, 2011. 364(21): p. 2006-2015. doi:https://doi.org/10.1056/NEJMoa1014350

24 Eberhardt, R., et al., Multimodality bronchoscopic diagnosis of peripheral lung lesions - A randomized controlled

Citations overall citation

rate

25.2

662

28.8

615 
Table 1 List of the 100 top-cited articles on bronchoscopy (Continued)

Rank Article Title Citations overall citation

rate

trial. American Journal of Respiratory and Critical Care Medicine, 2007. 176(1): p. 36-41. doi:https://doi.org/10.1164/ rccm.200612-18660C

25 Lam, S., et al., Detection of dysplasia and carcinoma in situ with a lung imaging fluorescence endoscope device. The Journal of thoracic and cardiovascular surgery, 1993. 105(6): p. 1035-40. doi:https://doi.org/10.1016/s00225223(19)33775-4

26 Ward, C., et al., Airway inflammation, basement membrane thickening and bronchial hyperresponsiveness in asthma. Thorax, 2002. 57(4): p. 309-316. doi:https://doi.org/10.1136/thorax.57.4.309

27 Heyland, D., et al., A randomized trial of diagnostic techniques for ventilator-associated pneumonia. New England Journal of Medicine, 2006. 355(25): p. 2619-2630. doi:https://doi.org/10.1056/NEJMoa052904

$28 \mathrm{Li}, \mathrm{X}$. and J.W. Wilson, Increased vascularity of the bronchial mucosa in mild asthma. American journal of respiratory and critical care medicine, 1997. 156(1): p. 229-33. doi:https://doi.org/10.1164/ajrccm.156.1.9607066

29 Yasufuku, K., et al., A prospective controlled trial of endobronchial ultrasound-guided transbronchial needle aspiration compared with mediastinoscopy for mediastinal lymph node staging of lung cancer. Journal of Thoracic and Cardiovascular Surgery, 2011. 142(6): p. 1393-1402. doi:https://doi.org/10.1016/j.jtcvs.2011.08.037

30 Saglani, S., et al., Early detection of airway wall remodeling and eosinophilic inflammation in preschool wheezers. American Journal of Respiratory and Critical Care Medicine, 2007. 176(9): p. 858-864. doi:https://doi.org/10.1164/ rccm.200702-2120C

31 Morris, A., et al., Comparison of the Respiratory Microbiome in Healthy Nonsmokers and Smokers. American Journal of Respiratory and Critical Care Medicine, 2013. 187(10): p. 1067-1075. doi:https://doi.org/10.1164/rccm.201210$19130 C$

32 Baaklini, W.A., et al., Diagnostic yield of fiberoptic bronchoscopy in evaluating solitary pulmonary nodules. Chest, 2000. 117(4): p. 1049-1054. doi:https://doi.org/10.1378/chest.117.4.1049

33 Meersseman, W., et al., Galactomannan in bronchoalveolar lavage fluid - A tool for diagnosing aspergillosis in intensive care unit patients. American Journal of Respiratory and Critical Care Medicine, 2008. 177(1): p. 27-34. doi: https://doi.org/10.1164/rccm.200704-6060C

34 Herth, F., H.D. Becker, and A. Ernst, Conventional vs endobronchial ultrasound-guided transbronchial needle aspiration - A randomized trial. Chest, 2004. 125(1): p. 322-325. doi:https://doi.org/10.1378/chest.125.1.322

35 Woodruff, P.G., et al., Hyperplasia of smooth muscle in mild to moderate asthma without changes in cell size or gene expression. American Journal of Respiratory and Critical Care Medicine, 2004. 169(9): p. 1001-1006. doi:https:// doi.org/10.1164/rccm.200311-15290C

36 Wallace, M.B., et al., Minimally invasive endoscopic staging of suspected lung cancer. Jama-Journal of the American Medical Association, 2008. 299(5): p. 540-546. doi:https://doi.org/10.1001/jama.299.5.540

37 Kurimoto, N., et al., Endobronchial ultrasonography using a guide sheath increases the ability to diagnose peripheral pulmonary lesions endoscopically. Chest, 2004. 126(3): p. 959-965. doi:https://doi.org/10.1378/chest.126.3.959

38 Roum, J.H., et al., Systemic deficiency of glutathione in cystic fibrosis. Journal of applied physiology (Bethesda, Md.: 1985), 1993. 75(6): p. 2419-24. doi:https://doi.org/10.1152/jappl.1993.75.6.2419

39 Gildea, T.R., et al., Electromagnetic navigation diagnostic bronchoscopy - A prospective study. American Journal of Respiratory and Critical Care Medicine, 2006. 174(9): p. 982-989. doi:https://doi.org/10.1164/rccm.200603-344OC

40 Makrygiannakis, D., et al., Smoking increases peptidylarginine deiminase 2 enzyme expression in human lungs and increases citrullination in BAL cells. Annals of the Rheumatic Diseases, 2008. 67(10): p. 1488-1492. doi:https://doi.org/ 10.1136/ard.2007.075192

41 Takizawa, $H_{\text {., }}$ et al., Increased expression of transforming growth factor-beta 1 in small airway epithelium from tobacco smokers and patients with chronic obstructive pulmonary disease (COPD). American Journal of Respiratory and Critical Care Medicine, 2001. 163(6): p. 1476-1483. doi:https://doi.org/10.1164/ajrccm.163.6.9908135

42 Muhlebach, M.S., et al., Quantitation of inflammatory responses to bacteria in young cystic fibrosis and control patients. American Journal of Respiratory and Critical Care Medicine, 1999. 160(1): p. 186-191. doi:https://doi.org/10. 1164/ajrccm.160.1.9808096

43 Rosenfeld, M., et al., Early pulmonary infection, inflammation, and clinical outcomes in infants with cystic fibrosis. Pediatric Pulmonology, 2001. 32(5): p. 356-366. doi:https://doi.org/10.1002/ppul.1144

44 Limper, A.H. and U.B. Prakash, Tracheobronchial foreign bodies in adults. Annals of internal medicine, 1990. 112(8): p. 604-9. doi:https://doi.org/10.7326/0003-4819-112-8-604

45 Pavord, I.D., et al., Safety and efficacy of bronchial thermoplasty in symptomatic, severe asthma. American Journal of 261 Respiratory and Critical Care Medicine, 2007. 176(12): p. 1185-1191. doi:https://doi.org/10.1164/rccm.200704-5710C

46 Schwartz, M.D., et al., Nuclear factor-kappa B is activated in alveolar macrophages from patients with acute respiratory distress syndrome. Critical care medicine, 1996. 24(8): p. 1285-92. doi:https://doi.org/10.1097/00003246- 
Table 1 List of the 100 top-cited articles on bronchoscopy (Continued)

\begin{tabular}{lr}
\hline Rank Article Title Citations overall citation \\
rate
\end{tabular}

199,608,000-00004

47 Soler, N., et al., Airway inflammation and bronchial microbial patterns in patients with stable chronic obstructive 255 pulmonary disease. European Respiratory Journal, 1999. 14(5): p. 1015-1022. doi:https://doi.org/10.1183/09031936.99. 14510159

48 Trigg, C.J., et al., Placebo-controlled immunopathologic study of four months of inhaled corticosteroids in asthma. American journal of respiratory and critical care medicine, 1994. 150(1): p. 17-22. doi:https://doi.org/10.1164/ajrccm. 150.1.8025745

49 Steinberg, K.P., et al., Evolution of bronchoalveolar cell populations in the adult respiratory distress syndrome. American journal of respiratory and critical care medicine, 1994. 150(1): p. 113-22. doi:https://doi.org/10.1164/ ajrccm.150.1.8025736

50 Driver, A.G., et al., Adenosine in bronchoalveolar lavage fluid in asthma. The American review of respiratory disease, 1993. 148(1): p. 91-7. doi:https://doi.org/10.1164/ajrccm/148.1.91

51 Baharloo, F., et al., Tracheobronchial foreign bodies - Presentation and management in children and adults. Chest, 1999. 115(5): p. 1357-1362. doi:https://doi.org/10.1378/chest.115.5.1357

52 Tremblay, A., et al., A Randomized Controlled Trial of Standard vs Endobronchial Ultrasonography-Guided Transbron- 249 chial Needle Aspiration in Patients With Suspected Sarcoidosis. Chest, 2009. 136(2): p. 340-346. doi:https://doi.org/ 10.1378/chest.08-2768

53 Groneberg, D.A., et al., Increased expression of transient receptor potential vanilloid-1 in airway nerves of chronic cough. American Journal of Respiratory and Critical Care Medicine, 2004. 170(12): p. 1276-1280. doi:https://doi.org/ $10.1164 / \mathrm{rccm} .200402-1740 \mathrm{C}$

54 Martin, R.J., et al., Airways inflammation in nocturnal asthma. The American review of respiratory disease, 1991. 143(2): p. 351-7. doi:https://doi.org/10.1164/ajrccm/143.2.351

55 Balough, K., et al., The relationship between infection and inflammation in the early stages of lung disease from cystic fibrosis. Pediatric pulmonology, 1995. 20(2): p. 63-70. doi:https://doi.org/10.1002/ppul.1950200203

56 Marquette, C.H., et al., Diagnostic tests for pneumonia in ventilated patients: prospective evaluation of diagnostic accuracy using histology as a diagnostic gold standard. American journal of respiratory and critical care medicine, 1995. 151(6): p. 1878-88. doi:https://doi.org/10.1164/ajrccm.151.6.7767535

57 Papazian, L., et al., Bronchoscopic or blind sampling techniques for the diagnosis of ventilator-associated pneumonia. American journal of respiratory and critical care medicine, 1995. 152(6 Pt 1): p. 1982-91. doi:https://doi.org/10. 1164/ajrccm.152.6.8520766

58 Olivieri, D., et al., Effect of short-term treatment with low-dose inhaled fluticasone propionate on airway inflammation and remodeling in mild asthma: a placebo-controlled study. American journal of respiratory and critical care medicine, 1997. 155(6): p. 1864-71. doi:https://doi.org/10.1164/ajrccm.155.6.9196087

59 Chastre, J., et al., Evaluation of bronchoscopic techniques for the diagnosis of nosocomial pneumonia. American journal of respiratory and critical care medicine, 1995. 152(1): p. 231-40. doi:https://doi.org/10.1164/ajrccm.152.1. 7599829

60 Rutgers, S.R., et al., Ongoing airway inflammation in patients with COPD who do not currently smoke. Thorax, 2000. 55(1): p. 12-18. doi:https://doi.org/10.1136/thorax.55.1.12

61 von Eiff, M., et al., Pulmonary aspergillosis: early diagnosis improves survival. Respiration; international review of thoracic diseases, 1995. 62(6): p. 341-7. doi:https://doi.org/10.1159/000196477

62 Marchant, J.M., et al., Evaluation and outcome of young children with chronic cough. Chest, 2006. 129(5): p. 11321141. doi:https://doi.org/10.1378/chest.129.5.1132

63 Qiu, Y.S., et al., Biopsy neutrophilia, neutrophil chemokine and receptor gene expression in severe exacerbations of chronic obstructive pulmonary disease. American Journal of Respiratory and Critical Care Medicine, 2003. 168(8): p. 968-975. doi:https://doi.org/10.1164/rccm.200208-7940C

64 Salvi, S.S., et al., Acute exposure to diesel exhaust increases IL-8 and GRO-alpha production in healthy human airways. American Journal of Respiratory and Critical Care Medicine, 2000. 161(2): p. 550-557. doi:https://doi.org/10. 1164/ajrccm.161.2.9905052

65 Utz, J.P., S.J. Swensen, and M.A. Gertz, Pulmonary amyloidosis. The Mayo Clinic experience from 1980 to 1993. Annals of internal medicine, 1996. 124(4): p. 407-13. doi:https://doi.org/10.7326/0003-4819-124-4-199,602,150-00004

66 Calhoun, W.J., et al., A common cold virus, rhinovirus 16, potentiates airway inflammation after segmental antigen bronchoprovocation in allergic subjects. The Journal of clinical investigation, 1994. 94(6): p. 2200-8. doi:https://doi. org/10.1172/jci117581

67 Fahy, J.V., et al., Comparison of samples collected by sputum induction and bronchoscopy from asthmatic and 10.1164/ajrccm.152.1.7599862 
Table 1 List of the 100 top-cited articles on bronchoscopy (Continued)

Rank Article Title

68 Morelon, E., et al., Characteristics of sirolimus-associated interstitial pneumonitis in renal transplant patients. Transplantation, 2001. 72(5): p. 787-790. doi:https://doi.org/10.1097/00007890-200,109,150-00008

69 Cavaliere, S., et al., Endoscopic treatment of malignant airway obstructions in 2008 patients. Chest, 1996. 110(6): p. 1536-42. doi:https://doi.org/10.1378/chest.110.6.1536

70 Sanchez-Nieto, J.M., et al., Impact of invasive and noninvasive quantitative culture sampling on outcome of ventilator-associated pneumonia: a pilot study. American journal of respiratory and critical care medicine, 1998 157(2): p. 371-6. doi:https://doi.org/10.1164/ajrccm.157.2.97-02039

71 Vining, D.J., et al., Virtual bronchoscopy. Relationships of virtual reality endobronchial simulations to actual bronchoscopic findings. Chest, 1996. 109(2): p. 549-53. doi:https://doi.org/10.1378/chest.109.2.549

72 Sethi, S., et al., Airway inflammation and bronchial bacterial colonization in chronic obstructive pulmonary disease. American Journal of Respiratory and Critical Care Medicine, 2006. 173(9): p. 991-998. doi:https://doi.org/10.1164/ rccm.200509-15250C

73 Toma, T.P., et al., Bronchoscopic volume reduction with valve implants in patients with severe emphysema. Lancet, 2003. 361(9361): p. 931-933. doi:https://doi.org/10.1016/s0140-6736(03)12762-6

74 Swenson, E.R., et al., Pathogenesis of high-altitude pulmonary edema - Inflammation is not an etiologic factor. Jama- 218 Journal of the American Medical Association, 2002. 287(17): p. 2228-2235. doi:https://doi.org/10.1001/jama.287.17. 2228

75 Pesci, A., et al., Inflammatory cells and mediators in bronchial lavage of patients with chronic obstructive pulmonary 215 disease. The European respiratory journal, 1998. 12(2): p. 380-6. doi:https://doi.org/10.1183/09031936.98.12020380

76 Thiberville, L., et al., In vivo imaging of the bronchial wall microstructure using fibered confocal fluorescence microscopy. American Journal of Respiratory and Critical Care Medicine, 2007. 175(1): p. 22-31. doi:https://doi.org/ $10.1164 / \mathrm{rccm} .200605-6840 \mathrm{C}$

77 Hirshberg, B., et al., Hemoptysis: etiology, evaluation, and outcome in a tertiary referral hospital. Chest, 1997. 112(2): p. 440-4. doi:https://doi.org/10.1378/chest.112.2.440

78 Schwarz, Y., et al., Real-time electromagnetic navigation bronchoscopy to peripheral lung lesions using overlaid CT images - The first human study. Chest, 2006. 129(4): p. 988-994. doi:https://doi.org/10.1378/chest.129.4.988

79 Conte, J.E., et al., Intrapulmonary pharmacokinetics of linezolid. Antimicrobial Agents and Chemotherapy, 2002. 46(5): p. 1475-1480. doi:https://doi.org/10.1128/aac.46.5.1475-1480.2002

80 Lamer, C., et al., Analysis of vancomycin entry into pulmonary lining fluid by bronchoalveolar lavage in critically ill patients. Antimicrobial agents and chemotherapy, 1993. 37(2): p. 281-6. doi:https://doi.org/10.1128/aac.37.2.281

81 Lee, H.S., et al., Real-time endobronchial ultrasound-guided transbronchial needle aspiration in mediastinal staging of non-small cell lung cancer - How many aspirations per target lymph node station? Chest, 2008. 134(2): p. 368374. doi:https://doi.org/10.1378/chest.07-2105

82 Diette, G.B., et al., Distraction therapy with nature sights and sounds reduces pain during flexible bronchoscopy - A 208 complementary approach to routine analgesia. Chest, 2003. 123(3): p. 941-948. doi:https://doi.org/10.1378/chest.123. 3.94

83 Warke, T.J., et al., Exhaled nitric oxide correlates with airway eosinophils in childhood asthma. Thorax, 2002. 57(5): p. 207 383-387. doi:https://doi.org/10.1136/thorax.57.5.383

84 Virchow, J.C., et al., Neurotrophins are increased in bronchoalveolar lavage fluid after segmental allergen provocation. American journal of respiratory and critical care medicine, 1998. 158(6): p. 2002-5. doi:https://doi.org/ 10.1164/ajrccm.158.6.9803023

85 Gizycki, M.J., et al., Myofibroblast involvement in the allergen-induced late response in mild atopic asthma. American 207 journal of respiratory cell and molecular biology, 1997. 16(6): p. 664-73. doi:https://doi.org/10.1165/ajrcmb.16.6. 9191468

86 Fagon, J.Y., et al., Characterization of distal bronchial microflora during acute exacerbation of chronic bronchitis. Use of the protected specimen brush technique in 54 mechanically ventilated patients. The American review of respiratory disease, 1990. 142(5): p. 1004-8. doi:https://doi.org/10.1164/ajrccm/142.5.1004

87 Barbato, A., et al., Epithelial damage and angiogenesis in the airways of children with asthma. American Journal of Respiratory and Critical Care Medicine, 2006. 174(9): p. 975-981. doi:https://doi.org/10.1164/rccm.200602-1890C

88 Morrison, D., et al., Epithelial permeability, inflammation, and oxidant stress in the air spaces of smokers. American Journal of Respiratory and Critical Care Medicine, 1999. 159(2): p. 473-479. doi:https://doi.org/10.1164/ajrccm.159.2. 9804080

89 Pham, L.H., et al., Diagnosis of nosocomial pneumonia in mechanically ventilated patients. Comparison of a plugged 205 telescoping catheter with the protected specimen brush. The American review of respiratory disease, 1991. 143(5 Pt 1): p. 1055-61. doi:https://doi.org/10.1164/ajrccm/143.5_Pt_1.1055

Citations overall citation

rate

11.9

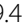


Table 1 List of the 100 top-cited articles on bronchoscopy (Continued)

\begin{tabular}{|c|c|c|c|}
\hline Rank & Article Title & Citations & $\begin{array}{l}\text { overall citation } \\
\text { rate }\end{array}$ \\
\hline 90 & $\begin{array}{l}\text { Angrill, J., et al., Bacterial colonisation in patients with bronchiectasis: microbiological pattern and risk factors. } \\
\text { Thorax, 2002. 57(1): p. 15-19. doi:https://doi.org/10.1136/thorax.57.1.15 }\end{array}$ & 204 & 11.3 \\
\hline 91 & $\begin{array}{l}\text { Ruiz, M., et al., Noninvasive versus invasive microbial investigation in ventilator-associated pneumonia - Evaluation of } \\
\text { outcome. American Journal of Respiratory and Critical Care Medicine, 2000. 162(1): p. 119-125. doi:https://doi.org/ } \\
\text { 10.1164/ajrccm.162.1.9907090 }\end{array}$ & 204 & 10.2 \\
\hline 92 & $\begin{array}{l}\text { Hattotuwa, K.L., et al., The effects of inhaled fluticasone on airway inflammation in chronic obstructive pulmonary } \\
\text { disease - A double-blind, placebo-controlled biopsy study. American Journal of Respiratory and Critical Care Medi- } \\
\text { cine, 2002. 165(12): p. 1592-1596. doi:https://doi.org/10.1164/rccm.2105025 }\end{array}$ & 203 & 11.3 \\
\hline 93 & $\begin{array}{l}\text { Verleden, G.M., et al., Azithromycin reduces airway neutrophilia and interleukin-8 in patients with bronchiolitis oblit- } \\
\text { erans syndrome. American Journal of Respiratory and Critical Care Medicine, 2006. 174(5): p. 566-570. doi:https:// } \\
\text { doi.org/10.1164/rccm.200601-0710C }\end{array}$ & 202 & 14.4 \\
\hline 94 & $\begin{array}{l}\text { Cox, G., et al., Bronchial thermoplasty for asthma. American Journal of Respiratory and Critical Care Medicine, } 2006 . \\
\text { 173(9): p. 965-969. doi:https://doi.org/10.1164/rccm.200507-11620C }\end{array}$ & 201 & 14.4 \\
\hline 95 & $\begin{array}{l}\text { Harrow, E.M., et al., The utility of transbronchial needle aspiration in the staging of bronchogenic carcinoma. } \\
\text { American Journal of Respiratory and Critical Care Medicine, 2000. 161(2): p. 601-607. doi:https://doi.org/10.1164/ } \\
\text { ajrccm.161.2.9902040 }\end{array}$ & 201 & 10.1 \\
\hline 96 & $\begin{array}{l}\text { Garwood, S., et al., Endobronchial ultrasound for the diagnosis of pulmonary sarcoidosis. Chest, 2007. 132(4): p. } \\
\text { 1298-1304. doi:https://doi.org/10.1378/chest.07-0998 }\end{array}$ & 200 & 15.4 \\
\hline 97 & $\begin{array}{l}\text { Armstrong, D.S., et al., Bronchoalveolar lavage or oropharyngeal cultures to identify lower respiratory pathogens in } \\
\text { infants with cystic fibrosis. Pediatric pulmonology, 1996. 21(5): p. 267-75. doi:https://doi.org/10.1002/(sici)1099- } \\
\text { 0496(199605)21:5 < 267::aid-ppul1 > 3.0.co;2-k }\end{array}$ & 198 & 8.3 \\
\hline 98 & $\begin{array}{l}\text { Pue, C.A. and E.R. Pacht, Complications of fiberoptic bronchoscopy at a university hospital. Chest, 1995. 107(2): p. } \\
\text { 430-2. doi:https://doi.org/10.1378/chest.107.2.430 }\end{array}$ & 198 & 7.9 \\
\hline 99 & $\begin{array}{l}\text { Molyneaux, P.L., et al., The Role of Bacteria in the Pathogenesis and Progression of Idiopathic Pulmonary Fibrosis. } \\
\text { American Journal of Respiratory and Critical Care Medicine, 2014. 190(8): p. 906-913. doi:https://doi.org/10.1164/ } \\
\text { rccm.201403-0541OC }\end{array}$ & 197 & 32.8 \\
\hline 100 & $\begin{array}{l}\text { Eberhardt, R., et al., Electromagnetic navigation diagnostic bronchoscopy in peripheral lung lesions. Chest, } 2007 . \\
\text { 131(6): p. 1800-1805. doi:https://doi.org/10.1378/chest.06-3016 }\end{array}$ & 196 & 15.1 \\
\hline
\end{tabular}

centrality in the 1990s (Fig. 7), while "diagnosis, BAL, biopsy, prospective, outcome, EBUS, evaluation" had a high degree of centrality in the 2000s (Fig. 8).

By ranking the Local Citation Score (LCS) index from high to low, we got the top 30 articles with the LCS of

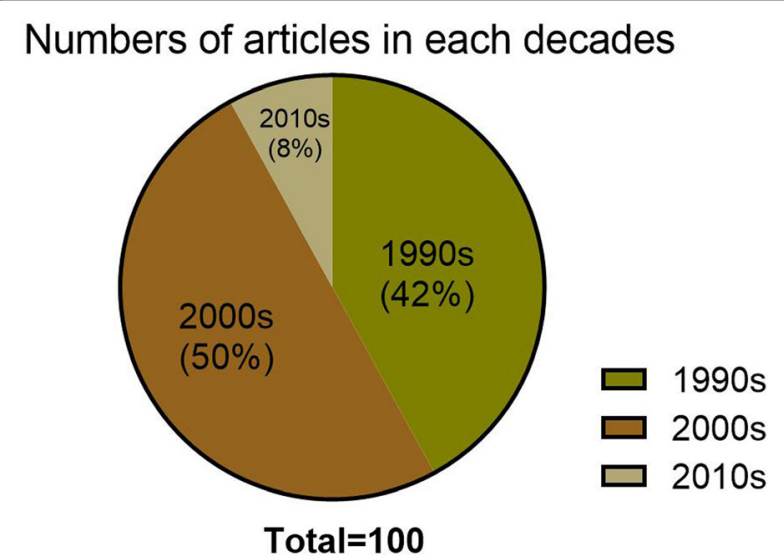

Fig. 2 Time distribution of 100 top-cited articles in bronchoscopy. A majority of articles were published in the 1990s $(42 \%, n=42)$ and 2000s $(50 \%, n=50)$
46 to 13 in HistCite Pro 2.1(Table 4). We compared them with the top 100 articles selected by the former method and found that 12 of them appeared again.

\section{Discussion}

As far as we can know, this is the first bibliometric analysis of papers on bronchoscopy. From the analysis of the top 100 most cited articles published on the theme of bronchoscopy, we can get several significant findings. The maximum number of citations in these articles reached 731, and this was a paper based on a bacteriologic analysis of BAL fluid for the diagnosis of ventilator-associated pneumonia [9]. When it comes to such relatively limited citation numbers, one explanation is that our analysis only focuses on articles published in the last 30 years, so there may not be enough time for them to be fully cited. Half of the top-cited articles were published in the 2000s, seconded by the 1990s with the article number of 42 in the top 100 most cited. The phenomenon of "obliteration by incorporation", which refers to articles no longer be cited when their substance has been treated as current knowledge [7], maybe exists in this analysis. Besides, there is an increasing trend between top-cited articles' citation density and their 


\section{Time-dependent overall citation rate trend}

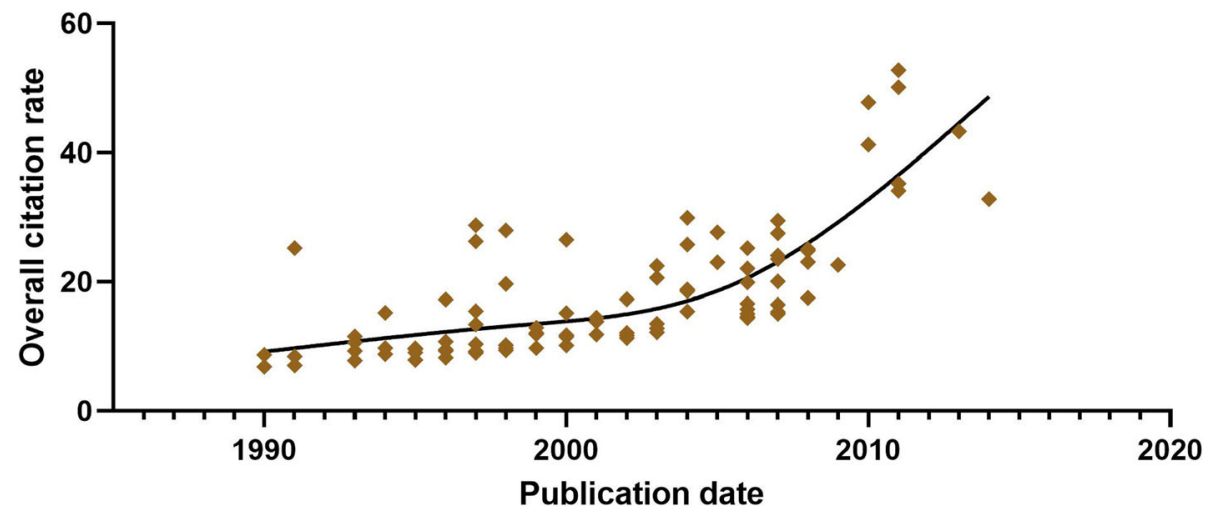

Fig. 3 Time-dependent citation density trend. Mann-Kendall trend test showed an increasing trend between the citation density and the time $(p<0.0001)$

published time, showing that more and more highquality articles are published in this field. Interestingly, there are eight articles published since 2010 making the top 100 most cited. The most recent literature in them was published in 2014, with the citation of 197 now [10]; followed by an article in 2013, with the citation of 303 here [11]. These results above also suggest that quite a few highly cited articles about bronchoscopy have appeared in the past 10 years.

We also have demonstrated the regional distribution of these articles. On the one hand, the majority of them originated from two regions, North America and Western Europe. Many research institutions there also performed well. For example, eight institutions each contributed three articles in the top 100 most cited, three of them (Mayo Clinic, National Jewish Medical and Research Center, and the University of California at San Francisco) from the USA, three of them (University of Southampton, University of London, and Royal Brompton Hospital) from the United Kingdom, along with Hospital Bichat and University of Barcelona from France and Spain individually. The reason for this phenomenon may be countries such as the USA and the United Kingdom have a fairly developed economy for supporting medical research. And it has previously been illustrated that a weak correlation exists between a country's gross domestic product per capita and its research achievements [12]. On the other hand, we can see that some papers are from Japan and Korea in

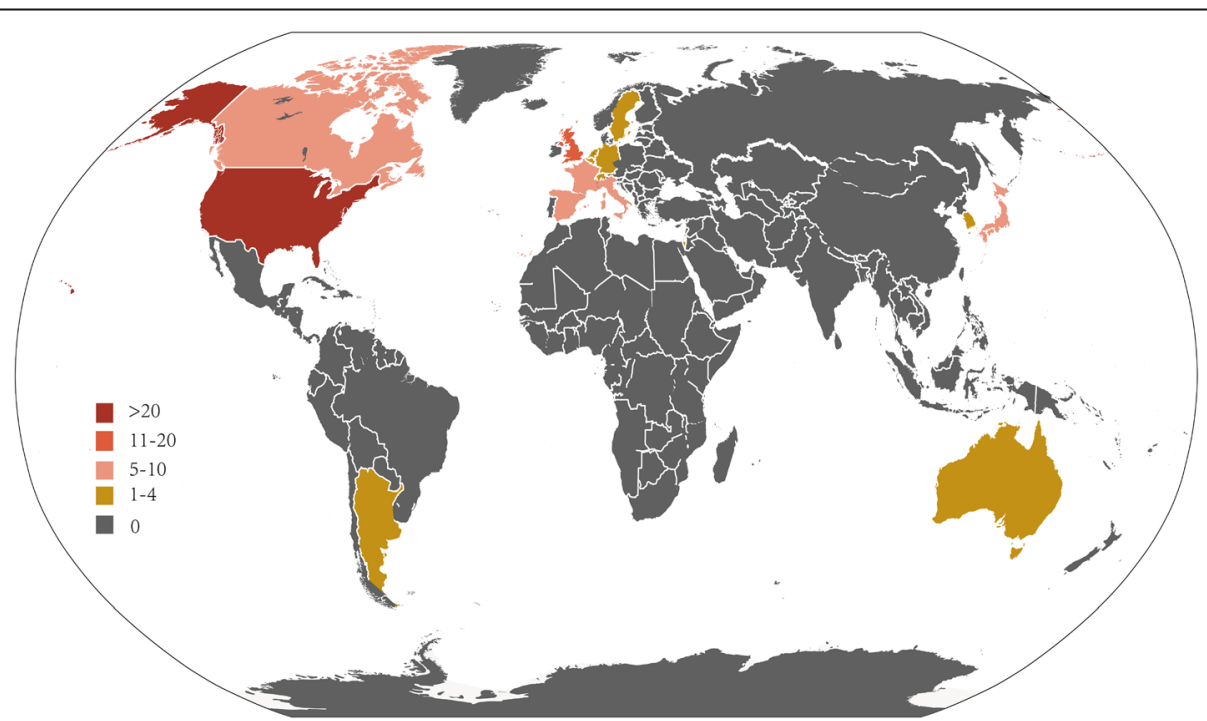

Fig. 4 Geographical distribution of all articles. The map showed that most articles came from two regions: North America and Western Europe (Due to limited space, the national borders are not completely accurate. This figure was modified based on an original image downloaded from Wikimedia Commons https://upload.wikimedia.org/wikipedia/commons/e/e7/GDP_per_capita-worldmap-2006.svg) 
Table 2 Journals with the most occurrences within the top-cited list and their impact factor (IF)

\begin{tabular}{lll}
\hline Journal name & No. of articles & IF (2019) \\
\hline American journal of respiratory and critical care medicine & 39 & 17.452 \\
Chest & 20 & 8.308 \\
The American review of respiratory disease & 5 & 17.452 \\
Thorax & 5 & 8.834 \\
New England Journal of Medicine & 4 & 74.699 \\
Annals of Internal Medicine & 3 & 21.317 \\
Pediatric Pulmonology & 3 & 2.534 \\
Critical Care Medicine & 2 & 7.414 \\
Jama-Journal of the American Medical Association & 2 & 45.54 \\
Antimicrobial Agents and Chemotherapy & 2 & 4.904
\end{tabular}

Asia, the Republic of Argentina in South America, and Australia in Oceania, suggesting that the application of bronchoscopy is universal and proving that this inspection technique has always been of research value once again. It means a lot that the research achievements from all these countries are shared in public so that more people can benefit from their studies.

We noticed that two journals contributed more than a half articles in the top 100 most cited, demonstrating strong professional attributes. They are American journal of respiratory and critical care medicine (AJRCCM) with the Impact Factor of 17.452 now and Chest Journal, whose Impact Factor in 2019 is 8.308. In our analysis, there are 39 articles from AJRCCM with 6 kinds of theme categories, and 20 articles from Chest also got involved in almost all of the themes we cared about. Among them, 9 articles of Chest and 3 articles of AJRCCM talked about the evaluation of new technologies, making up all articles in such category. Unlike the phenomenon in a similar bibliometric analysis of respiratory articles [13], it seems several core journals here gleaned a lot of citations. Apart from those specific journals in this field, some general medical journals such as The New England Journal of Medicine and Annals of Internal Medicine take an important part in this analysis, too. As for the authors, Yasufuku K, with the H-index of
47 when we searched, had four studies published between 2004 and 2011 imported in our study, performing the best. These studies were mainly based on endobronchial ultrasound-guided transbronchial needle aspiration for lymph node staging of lung cancer, and compared different examinations such as positron emission tomography and computed tomography (CT) [14-17].

From the perspective of published design, we also study the topic distribution characteristics of the most cited articles. Two themes, BAL fluid along with Bronchoscopy and biopsy, occupy the primary part. Since the application of bronchoscopy in clinical practice, the two have been the focus of researches in human bronchial and lung diseases as an important means of bronchoscopy sampling and testing.

BAL is widely used to sample the lower respiratory tract from the perspective of clinical bronchoscopy, and materials obtained in this way are mainly alveolar contents such as respiratory mucous secretions [18]. BAL is a technique for sampling respiratory epithelial fluid, and analysis of the cellular and non-cellular components of the reflow may provide valuable information about airway inflammation [19]. BAL fluid collected through bronchoscopy can be used for bacteriological analysis to diagnose related diseases, such as ventilator-associated pneumonia $[9,20]$. The keyword centrality analysis also

Table 3 List of first authors with the most occurrences within the top-cited list

\begin{tabular}{lll}
\hline First author & No. of articles & Affiliation \\
\hline Yasufuku K & 4 & Chiba University;Department Hospital de Sabadell; University of Toronto \\
Cox G & 2 & McMaster University \\
Eberhardt R & 2 & Ruprecht Karls University Heidelberg;Harvard University \\
Fagon JY & 2 & Hopital Bichat \\
Lam S & 2 & British Columbia Cancer Research Center \\
Luna CM & 2 & University of Buenos Aires \\
Spira A & 2 & Boston University \\
\hline
\end{tabular}




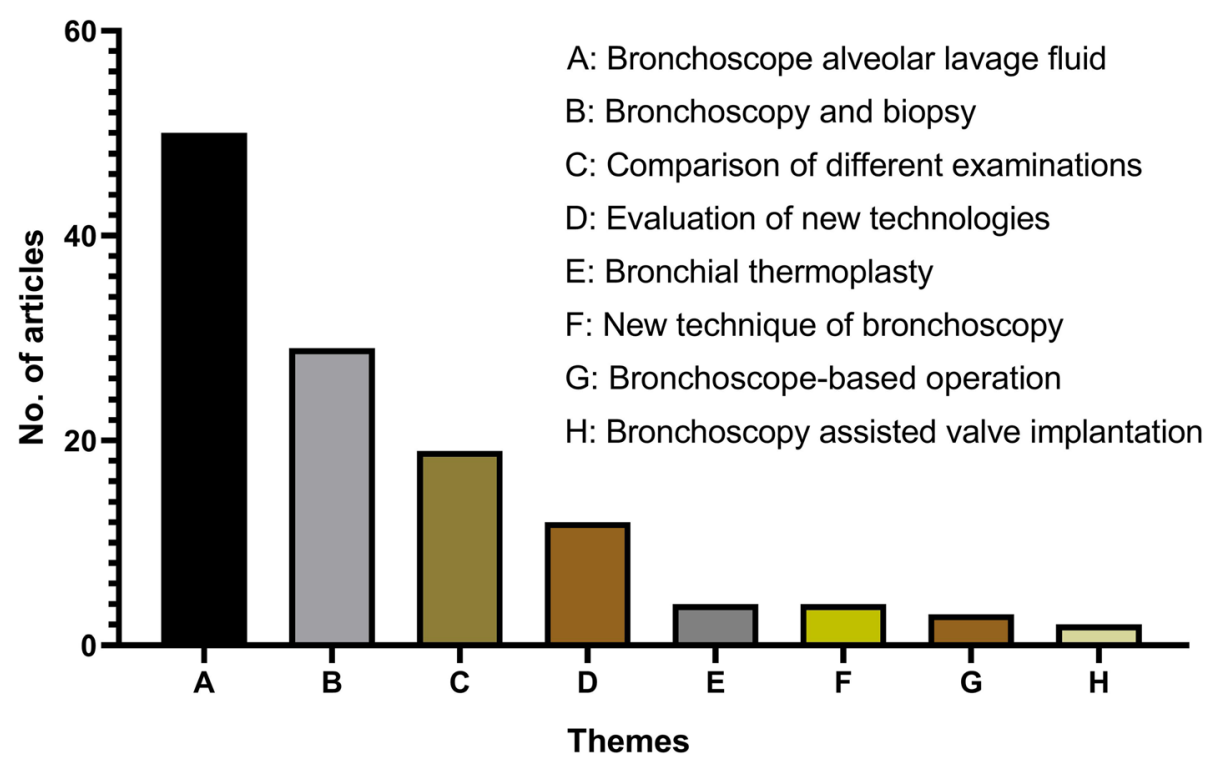

Fig. 5 The themes distribution of all the articles. The most mentioned theme was bronchoalveolar lavage fluid $(n=50)$, followed by bronchoscopy and biopsy $(n=29)$

shows that BAL had a high centrality in the 1990s and 2000s, showing such research direction is the absolute core, which is consistent with the research on subject words. These results suggest that BAL is still a bronchoscopy procedure that needs to be addressed in the future and that it is necessary to explore the drawbacks of this area, such as mucosal damage to the respiratory tract and invasive infections. Because of the invasive property, clinical workers should also be concerned about the possible damage to patients when using

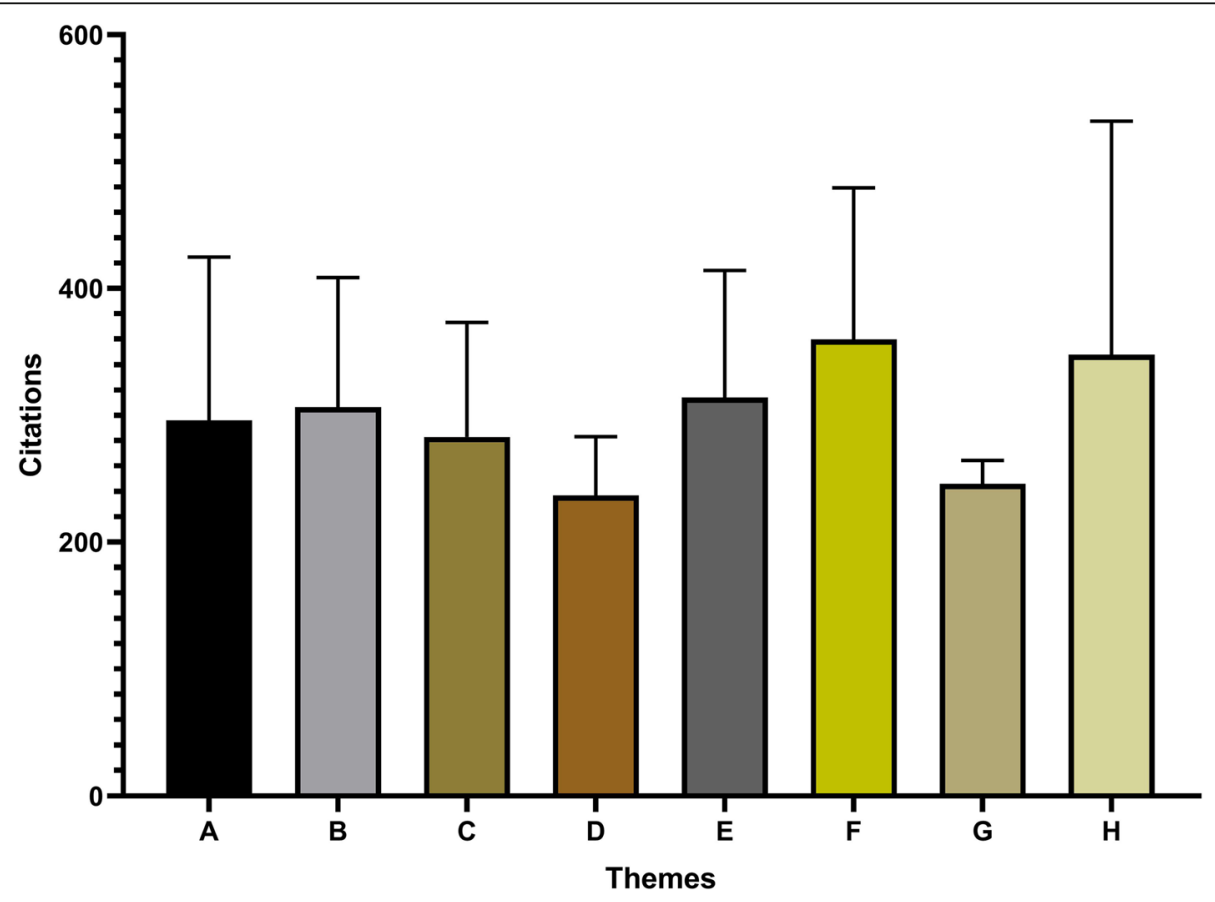

Fig. 6 Mean citation per article based on the theme. One-way ANOVA showed no significant difference in citations per article among the various themes $(P=0.486)$. A: bronchoalveolar lavage fluid, B: bronchoscopy and biopsy, C: comparison of different examinations, D: evaluation of new technologies, E: bronchial thermoplasty, F: new technique of bronchoscopy, G: bronchoscope-based operation, H: bronchoscopy assisted valve implantation 


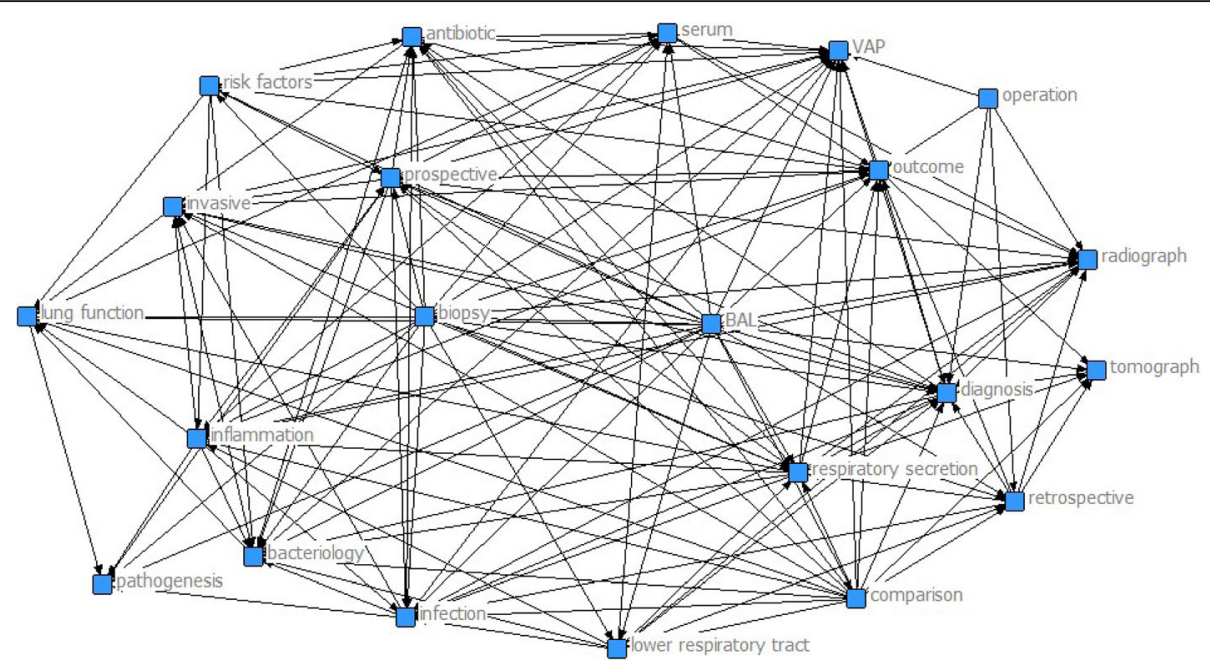

Fig. 7 Degree centrality analysis in the 1990s (42 articles). It showed that "BAL, inflammation, diagnosis, biopsy" had a high degree of centrality in the 1990s

bronchoscopy for BAL fluid sampling in the future. Research and development of BAL sampling technology with more safety and comfort is also a possible direction in the prospective technology field.

In addition to BAL, bronchoscopy and biopsy are other keywords with high involvement. As an important method of respiratory tract sampling, bronchoscopy biopsy plays an important role in the diagnosis of lung cancer and other bronchial-related diseases, the fibreoptic bronchoscopy has been routinely used for the diagnosis of suspected lung cancer [21]. It is reported that bronchoscopy can be considered as the safest and most accurate tool for assessing the mucous membranes of the central and distal airways [22]. We also found in some studies that both bronchoscopies with or without a narrow range and radial endobronchial ultrasound ( $R$ EBUS) were poorly diagnosed by the investigators for pulmonary lesions [23]. Thus, from a technical point of view, future work should focus on cutting edge technology to improve diagnostic accuracy.

As for the degree centrality analysis, there are differences between the 1990s and the 2000s. The hot words of the 1990s were those like BAL, inflammation, diagnosis, and biopsy. It is also consistent with the fact that there was a lot of attention paid to diagnosis in the 1990s. As for the 2000s, keywords with high-frequency became BAL, outcome, infection, and so on. Among them, it can be seen that researchers still pay high

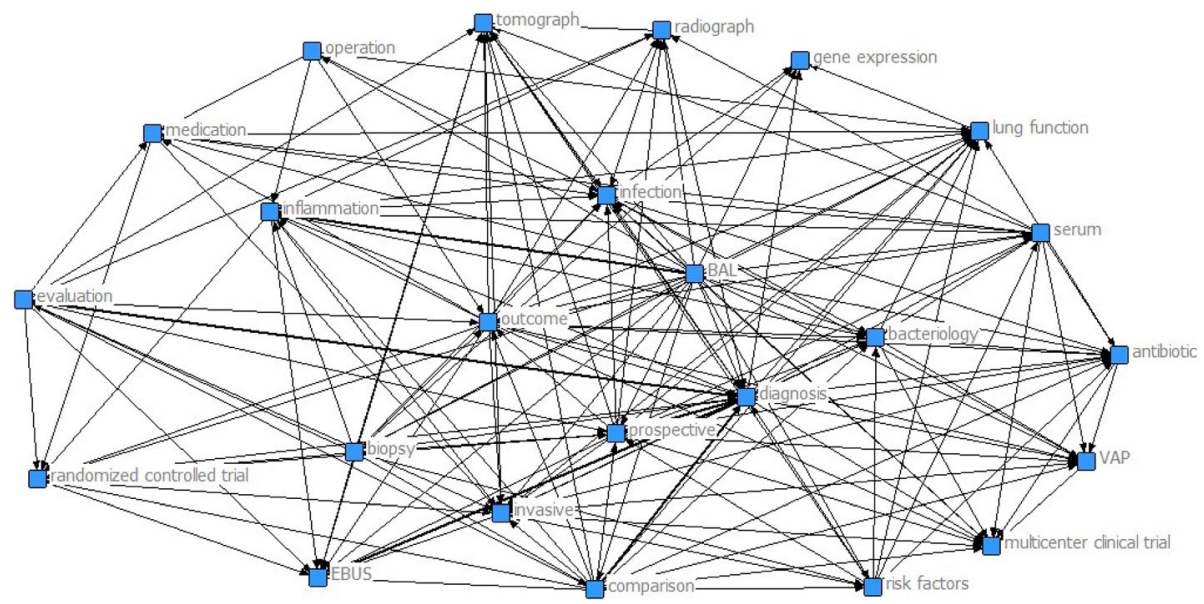

Fig. 8 Degree centrality analysis in the 2000s (50 articles). It showed that "diagnosis, BAL, biopsy, prospective, outcome, EBUS, evaluation" had a high degree of centrality in the 2000s 
Table 4 List of the top 30 local citation score (LCS) articles in top 1000 cited articles on bronchoscopy

\begin{tabular}{lll}
\hline Rank & Article Title & LCS \\
\hline $1^{\text {a }}$ & Baaklini, W.A., et al., Diagnostic yield of fiberoptic bronchoscopy in evaluating solitary pulmonary nodules. Chest, 2000. 117(4): p. 1049- \\
& 1054. doi: https://doi.org/10.1378/chest.117.4.1049
\end{tabular}

2 Schreiber, G. and D.C. McCrory, Performance characteristics of different modalities for diagnosis of suspected lung cancer - Summary of 29 published evidence. Chest, 2003. 123(1): p. 115S-128S. doi: https://doi.org/10.1378/chest.123.1_suppl.115S

$3^{\text {a }}$ Gildea, T.R., et al., Electromagnetic navigation diagnostic bronchoscopy - A prospective study. American Journal of Respiratory and Critical 28 Care Medicine, 2006. 174(9): p. 982-989. doi: https://doi.org/10.1164/rccm.200603-3440C

4 Kurimoto, N., et al., Assessment of usefulness of endobronchial ultrasonography in determination of depth of tracheobronchial tumor invasion. Chest, 1999. 115(6): p. 1500-1506. doi: https://doi.org/10.1378/chest.115.6.1500

$5^{\mathrm{a}} \quad$ Harrow, E.M., et al., The utility of transbronchial needle aspiration in the staging of bronchogenic carcinoma. American Journal of Respiratory and Critical Care Medicine, 2000. 161(2): p. 601-607. doi: https://doi.org/10.1164/ajrccm.161.2.9902040

$6^{\mathrm{a}} \quad$ Eberhardt, R., et al., Multimodality bronchoscopic diagnosis of peripheral lung lesions - A randomized controlled trial. American Journal of 22 Respiratory and Critical Care Medicine, 2007. 176(1): p. 36-41. doi: https://doi.org/10.1164/rccm.200612-18660C

$7^{\mathrm{a}} \quad$ Toma, T.P., et al., Bronchoscopic volume reduction with valve implants in patients with severe emphysema. Lancet, 2003. 361 (9361): p. 931-933. doi: https://doi.org/10.1016/s0140-6736(03)12762-6

8 Herth, F.J.F., A. Ernst, and H.D. Becker, Endobronchial ultrasound-guided transbronchial lung biopsy in solitary pulmonary nodules and per- 20 ipheral lesions. European Respiratory Journal, 2002. 20(4): p. 972-974. doi: https://doi.org/10.1183/09031936.02.00032001

$9^{\text {a }} \quad$ Schwarz, Y., et al., Real-time electromagnetic navigation bronchoscopy to peripheral lung lesions using overlaid CT images - The first hu- 20 man study. Chest, 2006. 129(4): p. 988-994. doi: https://doi.org/10.1378/chest.129.4.988

$10^{\mathrm{a}}$ Kurimoto, N., et al., Endobronchial ultrasonography using a guide sheath increases the ability to diagnose peripheral pulmonary lesions endoscopically. Chest, 2004. 126(3): p. 959-965. doi: https://doi.org/10.1378/chest.126.3.959

$11^{\mathrm{a}}$ Yasufuku, K., et al., Real-time endobronchial ultrasound-guided transbronchial needle aspiration of mediastinal and hilar lymph nodes. Chest, 2004. 126(1): p. 122-128. doi: https://doi.org/10.1378/chest.126.1.122

12 Venmans, B.J.W., et al., Outcome of bronchial carcinoma in situ. Chest, 2000. 117(6): p. 1572-1576. doi: https://doi.org/10.1378/chest.117.6. 1572

13 Garpestad, E., et al., CT fluoroscopy guidance for transbronchial needle aspiration - An experience in 35 patients. Chest, 2001. 119(2): p. 329-332. doi: https://doi.org/10.1378/chest.119.2.329

14 Paone, G., et al., Endobronchial ultrasound-driven biopsy in the diagnosis of peripheral lung lesions. Chest, 2005. 128(5): p. 3551-3557. doi: https://doi.org/10.1378/chest.128.5.3551

15 Schwarz, Y., et al., Electromagnetic navigation during flexible bronchoscopy. Respiration, 2003. 70(5): p. 516-522. doi: https://doi.org/10, $1159 / 000074210$

16 Snell, G.I., et al., The potential for bronchoscopic lung volume reduction using bronchial prostheses - A pilot study. Chest, 2003. 124(3): p. 1073-1080. doi: https://doi.org/10.1378/chest.124.3.1073

17 Shinagawa, N., et al., CT-guided transbronchial biopsy using an ultrathin bronchoscope with virtual bronchoscopic navigation. Chest, 2004. 125(3): p. 1138-1143. doi: https://doi.org/10.1378/chest.125.3.1138

18 Haponik, E.F., S.L. Aquino, and D.J. Vining, Virtual bronchoscopy. Clinics in Chest Medicine, 1999. 20(1): p. 201 - +. doi: https://doi.org/10. 1016/s0272-5231(05)70135-0

19 Hirsch, F.R., et al., Fluorescence versus white-light bronchoscopy for detection of preneoplastic lesions: a randomized study. Journal of the 16 National Cancer Institute, 2001. 93(18): p. 1385-1391. doi: https://doi.org/10.1093/jnci/93.18.1385

20 Herth, F.J.F., et al., Endobronchial ultrasound-guided transbronchial lung biopsy in fluoroscopically invisible solitary pulmonary nodules - A 16 prospective trial. Chest, 2006. 129(1): p. 147-150. doi: https://doi.org/10.1378/chest.129.1.147

21 Reichenberger, F., et al., The value of transbronchial needle aspiration in the diagnosis of peripheral pulmonary lesions. Chest, 1999. 116(3): p. 704-708. doi: https://doi.org/10.1378/chest.116.3.704

22 Hopkinson, N.S., et al., Effect of Bronchoscopic lung volume reduction on dynamic hyperinflation and exercise in emphysema. American Journal of Respiratory and Critical Care Medicine, 2005. 171(5): p. 453-460. doi: https://doi.org/10.1164/rccm.200407-9610C

$23^{\mathrm{a}}$ Eberhardt, R., et al., Electromagnetic navigation diagnostic bronchoscopy in peripheral lung lesions. Chest, 2007. 131 (6): p. 1800-1805. doi: 15 https://doi.org/10.1378/chest.06-3016

24 Bota, S., et al., Follow-up of bronchial precancerous lesions and carcinoma in situ using fluorescence endoscopy. American Journal of Respiratory and Critical Care Medicine, 2001. 164(9): p. 1688-1693. doi: https://doi.org/10.1164/ajrccm.164.9.2012147

$25^{\mathrm{a}}$ Herth, F., H.D. Becker, and A. Ernst, Conventional vs endobronchial ultrasound-guided transbronchial needle aspiration - A randomized trial. Chest, 2004. 125(1): p. 322-325. doi: https://doi.org/10.1378/chest.125.1.322

26 Kikuchi, E., et al., Endobronchial ultrasonography with guide-sheath for peripheral pulmonary lesions. European Respiratory Journal, 2004. 24(4): p. 533-537. doi: https://doi.org/10.1183/09031936.04.00138603

27 Shirakawa, T., et al., Usefulness of endobronchial ultrasonography for transbronchial lung biopsies of peripheral lung lesions. Respiration, 14 2004. 71(3): p. 260-268. doi: https://doi.org/10.1159/000077424 
Table 4 List of the top 30 local citation score (LCS) articles in top 1000 cited articles on bronchoscopy (Continued)

\begin{tabular}{|c|c|c|}
\hline Rank & Article Title & LCS \\
\hline 28 & $\begin{array}{l}\text { Asahina, H., et al., Transbronchial biopsy using endobronchial ultrasonography with a guide sheath and virtual bronchoscopic navigation. } \\
\text { Chest, 2005. 128(3): p. 1761-1765. doi: https://doi.org/10.1378/chest.128.3.1761 }\end{array}$ & 14 \\
\hline $29^{a}$ & $\begin{array}{l}\text { Yasufuku, K., et al., Endobronchial ultrasound guided transbronchial needle aspiration for staging of lung cancer. Lung Cancer, 2005. 50(3): } \\
\text { p. 347-354. doi: https://doi.org/10.1016/j.lungcan.2005.07.013 }\end{array}$ & 14 \\
\hline $30^{\mathrm{a}}$ & $\begin{array}{l}\text { Fagon, J.Y., et al., Invasive and noninvasive strategies for management of suspected ventilator-associated pneumonia - A randomized trial. } \\
\text { Annals of Internal Medicine, 2000. 132(8): p. } 621 \text { - +. doi: https://doi.org/10.7326/0003-4819-132-8-200,004,180-00004 }\end{array}$ & 13 \\
\hline
\end{tabular}

${ }^{a}$ The same articles appeared in Table 1

attention to the highest-frequency BAL. In addition, the focus of the 1990s on the diagnostic and technical aspects of treatment has shifted, with researchers focusing more on the evaluation of prognosis, infection control, and other aspects of treatment with bronchoscopy. Research on a number of treatments such as bronchial thermoplasty [24-26], bronchial valve implantation [27-29], and bronchoscopic removal of the tracheal foreign body [30] began to expand. Gradually, the study of bronchoscopy began to blossom.

The LCS represents the number of citations that a document has in the local data set. If a document has a high LCS value, we'd say it's an important document in the special field and may even be a groundbreaking article [31]. Chronologically, we can notice these 30 articles obtained by using the LCS method in the 1000 most cited articles published from 1990 to 2020 actually ranged from 1999 to 2007, and even one-fifth of them presented in one single year, 2004. In connection with the previous analysis that the 2000s made the most articles in three decades, this interesting phenomenon may suggest that the research on bronchoscopy has been further expanded and deepened in these years. There is a consistency between the two methods because of 12 overlapping articles obtained. Throughout these 12 articles on the topic of research, more than half linked with E-BUS. This reflects a high research interest in this technology in the 2000s. For example, Yasufuku et al. pointed out in 2004 that lymph node sampling of hilum and mediastinum by EBUS-guided transbronchial needle aspiration (TBNA) technique was accurate and safe in diagnosing pulmonary diseases [14]. This research, in our analysis, has a citation number of 479 (Ranked 6th) and the LCS of 19. Electromagnetic navigation bronchoscopy (ENB) is another hot theme in 12 articles. It was concluded that ENB is a safe and effective diagnostic technique in the years around 2006 [32, 33], which has led to broad studies. These new techniques have undoubtedly received more and more attention, suggesting important directions for bronchoscopy research in the future.

We also took note of the progress of bronchoscopyrelated research in recent years. Some researchers pointed out that bronchoscopic lung volume reduction using an endobronchial valve (EBV) is safe and effective in the treatment of chronic respiratory diseases such as emphysema. And with advances in one-way valve therapy, this is now a routine treatment option [34]; Bronchoscopic lung cryobiopsy, a novel biopsy method, was thought to have a meaningful effect on the multidisciplinary diagnosis of idiopathic pulmonary fibrosis [35]; Endoscopic ultrasound with bronchoscope fine needle aspiration (EUS-BFNA) is a new technique which can be performed by interventional pulmonologists/thoracic surgeons with an echo-bronchoscope. With the help of EBUS, doctors can explore all the mediastinal lymph node stations in one endoscopic session, improving the accuracy in the diagnosis and staging of lung cancer [36]; Newer navigational modalities, such as robotic bronchoscopy and CT-guided cone beam bronchoscopy, might foreshadow the future in the bronchoscopic management of peripheral pulmonary lesions [37, 38]; Besides, a recent study illustrated the role of bronchoscopy in the management of hemoptysis, which still represents a frequent diagnostic challenge in routine clinical practice [39]. Those novel developments are so fantastic and instructive, while whether they are highquality researches or not need more time to test. We will continue to monitor the progress of the discipline.

Admittedly, although our results produce some valuable information, which may play a certain role in suggesting the topic selection and research direction of intending researchers, there are also some limitations. First, as articles are filtered according to the number of citations, new publications that are significant in the field but have not yet reached high citation levels are ignored. Therefore, it tends to be a kind of retrospective study of historical articles. Second, this analysis included only published articles and excluded other papers like clinical guidelines, meeting notes, textbooks, meta-analyses, and reviews, which may lead to omission bias. Thirdly, although we did search without any language restrictions on Web of Science, some famous articles in languages other than English may have been omitted because of database limits. Last but not least, although we use bronchoscopy as the keyword to search for articles, we may miss some famous articles retrieved by other keywords.

\section{Conclusions}

This article highlights the top 100 most cited articles in bronchoscopy over the past 30 years (1990-2020), 
including their time and geographical distribution, research topics, authors, research institutions, and research keywords. From the aspect of the research theme, we found that BAL and bronchial biopsies currently plays a major role. At the same time, they mostly focus on clinical trials, whereas basic laboratory research is inadequate, so more research on the subject is needed. In addition, because of the inherent limitation of our analysis, novel and instructive researches such as fluorescent bronchoscopy and advanced electromagnetic guided bronchoscopy may fail to enter our horizons. In summary, the field of bronchoscopy looks promising. With the advent of modern technology and easy access to different data, we can look forward to getting deeper researches in this area during the next $5-10$ years.

\section{Supplementary information}

Supplementary information accompanies this paper at https://doi.org/10. 1186/s12890-020-01266-9.

\section{Additional file 1.}

\section{Abbreviations}

BAL: Bronchoalveolar lavage; ANOVA: Analysis of variance; LCS: Local citation score; AJRCCM: American journal of respiratory and critical care medicine; $C T$ : Computed tomography; R-EBUS: Radial endobronchial ultrasound; TBNA: Transbronchial needle aspiration; ENB: Electromagnetic navigation bronchoscopy; EBV: Endobronchial valve; EUS-B-FNA: Endoscopic ultrasound with bronchoscope fine needle aspiration

\section{Acknowledgements}

Not applicable.

\section{Authors' contributions}

All authors contributed to the study conception and design. XW conceived and designed the work. Material preparation and data collection and analysis were performed by $B H, P Z, Q C, S S, H X, Y Z X P, Z Z$, and $W Y$. The first draft of the manuscript was written by $\mathrm{BH}$ and $\mathrm{PZ}$, and all authors commented on previous versions of the manuscript. Then, QC revised the manuscript and all authors read and approved the final manuscript.

\section{Funding}

This work was supported by the National Natural Science Foundation of China (81672308, X. Wang) and the Hunan Provincial Key Area R\&D Programmes (2019SK2253, X. Wang). The funders had no role in the design of the study, the collection, analysis or interpretation of data, or the writing of the manuscript.

\section{Availability of data and materials}

All data generated or analysed during this study are included in this published article and its supplementary information file.

\section{Ethics approval and consent to participate}

Not applicable.

\section{Consent for publication}

Not applicable.

\section{Competing interests}

The authors declare that they do not have any competing interests.
Received: 20 July 2020 Accepted: 17 August 2020

Published online: 27 August 2020

\section{References}

1. Ninan N, Wahidi MM. Basic bronchoscopy: technology, techniques, and professional fees. Chest. 2019;155(5):1067-74.

2. Rano A, Agusti C, Benito N, Rovira M, Angrill J, Pumarola T, Torres A. Prognostic factors of non-HIV immunocompromised patients with pulmonary infiltrates. Chest. 2002;122(1):253-61.

3. Thiberville L, Moreno-Swirc S, Vercauteren T, Peltier E, Cave C, Bourg Heckly G. In vivo imaging of the bronchial wall microstructure using fibered confocal fluorescence microscopy. Am J Respir Crit Care Med. 2007;175(1):22-31.

4. Busse WW, Wanner A, Adams K, Reynolds HY, Castro M, Chowdhury B, Kraft M, Levine RJ, Peters SP, Sullivan EJ. Investigative bronchoprovocation and bronchoscopy in airway diseases. Am J Respir Crit Care Med. 2005;172(7):807-16.

5. Denning DW, Cadranel J, Beigelman-Aubry C, Ader F, Chakrabarti A, Blot S, Ullmann AJ, Dimopoulos G, Lange C. Chronic pulmonary aspergillosis: rationale and clinical guidelines for diagnosis and management. Eur Respir J. 2016;47(1):45-68.

6. Ashraf SF, Lau KKW. Navigation bronchoscopy: A new tool for pulmonary infections. Med Mycol. 2019;57(Supplement_3):S287-s293.

7. Garfield E. 100 citation classics from the journal of the American Medical Association. Jama. 1987;257(1):52-9.

8. Jin K, Hu Q, Xu J, Wu C, Hsin MK, Zirafa CC, Novoa NM, Bongiolatti S, Cerfolio RJ, Shen J, et al. The 100 most cited articles on thoracic surgery management of lung cancer. J Thorac Dis. 2019;11(11):4886-903.

9. Pugin J, Auckenthaler R, Mili N, Janssens JP, Lew PD, Suter PM. Diagnosis of ventilator-associated pneumonia by bacteriologic analysis of bronchoscopic and nonbronchoscopic "blind" bronchoalveolar lavage fluid. Am Rev Respir Dis. 1991;143(5 Pt 1):1121-9.

10. Molyneaux PL, Cox MJ, Willis-Owen SA, Mallia P, Russell KE, Russell AM, Murphy E, Johnston SL, Schwartz DA, Wells AU, et al. The role of bacteria in the pathogenesis and progression of idiopathic pulmonary fibrosis. Am J Respir Crit Care Med. 2014;190(8):906-13.

11. Morris A, Beck JM, Schloss PD, Campbell TB, Crothers K, Curtis JL, Flores SC, Fontenot AP, Ghedin E, Huang $L$, et al. Comparison of the respiratory microbiome in healthy nonsmokers and smokers. Am J Respir Crit Care Med. 2013;187(10):1067-75

12. Zhang W, Tang N, Li X, George DM, He G, Huang T. The top 100 most cited articles on total hip arthroplasty: a bibliometric analysis. J Orthop Surg Res. 2019:14(1):412.

13. Seriwala HM, Khan MS, Shuaib W, Shah SR. Bibliometric analysis of the top 50 cited respiratory articles. Expert Rev Respir Med. 2015;9(6):817-24.

14. Yasufuku K, Chiyo M, Sekine Y, Chhajed PN, Shibuya K, lizasa T, Fujisawa T. Real-time endobronchial ultrasound-guided transbronchial needle aspiration of mediastinal and hilar lymph nodes. Chest. 2004;126(1):122-8.

15. Yasufuku K, Chiyo M, Koh E, Moriya Y, lyoda A, Sekine Y, Shibuya K, lizasa T, Fujisawa T. Endobronchial ultrasound guided transbronchial needle aspiration for staging of lung cancer. Lung Cancer. 2005;50(3):347-54.

16. Yasufuku $K$, Pierre A, Darling $G$, de Perrot $M$, Waddell $T$, Johnston $M$, da Cunha SG, Geddie W, Boerner S, Le LW, et al. A prospective controlled trial of endobronchial ultrasound-guided transbronchial needle aspiration compared with mediastinoscopy for mediastinal lymph node staging of lung cancer. J Thorac Cardiovasc Surg. 2011;142(6):1393-400 e1391.

17. Yasufuku K, Nakajima T, Motoori K, Sekine Y, Shibuya K, Hiroshima K Fujisawa T. Comparison of endobronchial ultrasound, positron emission tomography, and CT for lymph node staging of lung cancer. Chest. 2006; 130(3):710-8.

18. Rennard SI, Ghafouri M, Thompson AB, Linder J, Vaughan W, Jones K, Ertl RF, Christensen K, Prince A, Stahl MG. Fractional processing of sequential bronchoalveolar lavage to separate bronchial and alveolar samples. Am Rev Respir Dis. 1990;141(1):208-17.

19. Connett GJ. Bronchoalveolar lavage. Paediatr Respir Rev. 2000;1(1):52-6.

20. Armstrong DS, Grimwood K, Carlin JB, Carzino R, Olinsky A, Phelan PD. Bronchoalveolar lavage or oropharyngeal cultures to identify lower respiratory pathogens in infants with cystic fibrosis. Pediatr Pulmonol. 1996; 21(5):267-75.

21. Kawaraya M, Gemba K, Ueoka H, Nishii K, Kiura K, Kodani T, Tabata M, Shibayama T, Kitajima T, Tanimoto M. Evaluation of various cytological examinations by bronchoscopy in the diagnosis of peripheral lung cancer. Br J Cancer. 2003;89(10):1885-8. 
22. Andolfi M, Potenza R, Capozzi R, Liparulo V, Puma F, Yasufuku K. The role of bronchoscopy in the diagnosis of early lung cancer: a review. J Thorac Dis. 2016:8(11):3329-37.

23. Tanner NT, Yarmus L, Chen A, Wang Memoli J, Mehta HJ, Pastis NJ, Lee $H$, Jantz MA, Nietert PJ, Silvestri GA. Standard bronchoscopy with fluoroscopy vs thin bronchoscopy and radial Endobronchial ultrasound for biopsy of pulmonary lesions: a multicenter, prospective, radomized trial. Chest. 2018; 154(5):1035-43.

24. Cox G, Miller JD, McWilliams A, FitzGerald JM, Lam S. Bronchial thermoplasty for asthma. Am J Respir Crit Care Med. 2006;173(9):965-9.

25. Cox G, Thomson NC, Rubin AS, Niven RM, Corris PA, Siersted HC, Olivenstein R, Pavord ID, McCormack D, Chaudhuri R, et al. Asthma control during the year after bronchial thermoplasty. N Engl J Med. 2007;356(13):1327-37.

26. Pavord ID, Cox G, Thomson NC, Rubin AS, Corris PA, Niven RM, Chung KF, Laviolette M, Grp RTS. Safety and efficacy of bronchial thermoplasty in symptomatic, severe asthma. Am J Respir Crit Care Med. 2007;176(12):1185-91.

27. Snell GI, Holsworth L, Borrill ZL, Thomson KR, Kalff V, Smith JA, Williams TJ. The potential for bronchoscopic lung volume reduction using bronchial prostheses - a pilot study. Chest. 2003;124(3):1073-80.

28. Toma TP, Hopkinson NS, Hillier J, Hansell DM, Morgan C, Goldstraw PG, Polkey MI, Geddes DM. Bronchoscopic volume reduction with valve implants in patients with severe emphysema. Lancet. 2003;361(9361):931-3.

29. Hopkinson NS, Toma TP, Hansell DM, Goldstraw P, Moxharn J, Geddes DM, Polkey MI. Effect of Bronchoscopic lung volume reduction on dynamic hyperinflation and exercise in emphysema. Am J Respir Crit Care Med. 2005; 171(5):453-60.

30. Tan HKK, Brown K, McGill T, Kenna MA, Lund DP, Healy GB. Airway foreign bodies (FB): a 10-year review. Int J Pediatr Otorhinolaryngol. 2000;56(2):91-9.

31. Hao X, Liu Y, Li X, Zheng J. Visualizing the history and perspectives of disaster medicine: a Bibliometric analysis. Disaster Med Public Health Prep. 2019;13(5-6):966-73.

32. Gildea TR, Mazzone PJ, Karnak D, Meziane M, Mehta AC. Electromagnetic navigation diagnostic bronchoscopy - a prospective study. Am J Respir Crit Care Med. 2006;174(9):982-9.

33. Eberhardt R, Anantham D, Herth F, Feller-Kopman D, Ernst A. Electromagnetic navigation diagnostic bronchoscopy in peripheral lung lesions. Chest. 2007:131(6):1800-5.

34. Hartman JE, Vanfleteren LEGW, van Rikxoort EM, Klooster K, Slebos DJ. Endobronchial valves for severe emphysema. Eur Respir Rev. 2019;28(152): 180121.

35. Tomassetti S, Wells AU, Costabel U, Cavazza A, Colby TV, Rossi G, Sverzellati N, Carloni A, Carretta E, Buccioli M, et al. Bronchoscopic lung Cryobiopsy increases diagnostic confidence in the multidisciplinary diagnosis of idiopathic pulmonary fibrosis. Am J Respir Crit Care Med. 2016;193(7):745-52.

36. Vilmann P, Clementsen PF, Colella S, Siemsen M, De Leyn P, Dumonceau JM, Herth FJ, Larghi A, Vazquez-Sequeiros E, Hassan C, et al. Combined endobronchial and oesophageal endosonography for the diagnosis and staging of lung cancer. European Society of Gastrointestinal Endoscopy (ESGE) guideline, in cooperation with the European Respiratory Society (ERS) and the European Society of Thoracic Surgeons (ESTS). Eur Respir J. 2015;46(1):40-60

37. Chaddha U, Kovacs SP, Manley C, Hogarth DK, Cumbo-Nacheli G, Bhavani SV, Kumar R, Shende M, Egan JP 3rd, Murgu S. Robot-assisted bronchoscopy for pulmonary lesion diagnosis: results from the initial multicenter experience. BMC Pulm Med. 2019;19(1):243.

38. Cheng GZ, Liu L, Nobari M, Miller R, Wahidi M. Cone beam navigation bronchoscopy: the next frontier. J Thorac Dis. 2020;12(6):3272-8.

39. Mondoni M, Carlucci P, Cipolla G, Fois A, Gasparini S, Marani S, Centanni S, Sotgiu G. Bronchoscopy to assess patients with hemoptysis: which is the optimal timing? BMC Pulm Med. 2019;19(1):36.

\section{Publisher's Note}

Springer Nature remains neutral with regard to jurisdictional claims in published maps and institutional affiliations.

Ready to submit your research? Choose BMC and benefit from:
- fast, convenient online submission
- thorough peer review by experienced researchers in your field
- rapid publication on acceptance
- support for research data, including large and complex data types
- gold Open Access which fosters wider collaboration and increased citations
- maximum visibility for your research: over 100M website views per year
At BMC, research is always in progress.
Learn more biomedcentral.com/submissions

